\title{
Putative neurotransmitters in the rat cochlea at several ages
}

\author{
Douglas W. Hoffman ${ }^{1}$, Kitty Lea Jones-King ${ }^{1}$ and Richard A. Altschuler ${ }^{2}$ \\ ${ }^{\prime}$ Neurochemistry Laboratory, Departments of Psychiatry and Pharmacology, Dartmouth Medical School, Hanover, NH (U.S.A.) and \\ ${ }^{2}$ Kresge Hearing Research Institute, University of Michigan, Ann Arbor, MI (U.S.A.)
}

(Accepted 31 May 1988)

Key words: Cochlea; Aging; Presbycusis; Enkephalin; Dynorphin; Acetylcholine

\begin{abstract}
We have performed a longitudinal study of the content of the putative neurotransmitter substances, enkephalin, dynorphin, and acetylcholine $(\mathrm{ACh})$, in the cochlea of the Fischer 344 rat. It is the first study of transmitters in the rat cochlea over an extended time span. This study also provides biochemical verification of the presence of $\mathrm{ACh}$ in cochlear tissues. No change was seen in the cochlear content of these transmitter candidates up to 24 months of age.
\end{abstract}

In the past several years it has become clear that there are anatomically and chemically distinct efferent systems innervating the cochlea; the lateral system, which terminates on eight nerve dendrites under inner hair cells, and the medial, which directly innervates outer hair cells $s^{14,30,31}$. The lateral efferents of species studied to date are known to contain enkephalins, dynorphins, calcitonin gene-related peptide and acetylcholine ( $\mathrm{ACh}$ ), while in the medial system only $\mathrm{ACh}$ has so far been identified as a putative transmitter substance $e^{1-12.16 .18-20.23 .24}$.

A considerable body of evidence has been developed supporting a role for acetylcholine as the transmitter of the efferent fibers arising in the superior olivary region which innervate the cochlea. Acetylcholine has been identified by bioassay in one mammalian cochlea ${ }^{28}$, and enzymes related to the synthesis and degradation of ACh have been similarly localized by histochemical and biochemical means s., $^{1,3}$ 5.13.21. Acetylcholine has also been shown to mimic in certain respects electrical stimulation of the cochlear efferents ${ }^{8}$.

Both proenkephalin- and prodynorphin-derived peptides have been identified in cochlear tissues and fluids, and have been localized by immunocytochemical, histochemical and biochemical techniques to the olivocochlear efferent fibers innervating the cochlea $a^{1-7,9.12 .16 .18-20.23}$. These include enkephalins, dynorphins and neo-endorphins. Opioid receptors as well have been reported in the cochlea ${ }^{10,20}$. Enkephalin- and dynorphin-like immunoreactivities have also been seen in the same cells in the superior olivary region ${ }^{1.7}$, as have opioid peptide-like and choline acetyltransferase-like immunoreactivity ${ }^{1,3}$, and enkephalin-like immunoreactivity and acetylcholinesterase activity ${ }^{5}$.

Acetylcholine and opioid peptides appear to serve as neurotransmitters or neuromodulators of the superior olivary fibers in the cochlea. The manner in which they may interact with each other, and the reasons for their co-localization at these synapses, have not yet been elucidated. In the course of studying these neuroactive substances we have determined their levels in the rat cochlea at different stages in the life span. Fischer 344 rats at 3,12 and 24 months of age were used, representing the mature adult, old adult, and the extreme of the normal life span, respectively.

The combined high-performance liquid chromatography-radioimmunoassay (HPLC-RIA) for enkephalins has been described in earlier publications ${ }^{17.18}$. Whole cochleas were sonicated in $7.5 \mathrm{mM}$

Correspondence: D.W. Hoffman. Department of Psychiatry-HB7770. Dartmouth Medical School, Hanover, NH 03756. U.S.A. 
trifluoroacetic acid in $25 \%$ acetonitrile and centrifuged. Supernatants were either chromatographed for enkephalins and dynorphin, or lyophilized directly in a vacuum centrifuge. Dynorphin B chromatographed as a single sharp peak using the same HPLC method as used for enkephalins. Dynorphin was assayed as dynorphin B (rimorphin) using a commercially available kit (Peninsula Labs). This antiserum does not cross-react with other dynorphins, endorphins or dynorphins, and so results were the same whether or not samples were chromatographed prior to assay. Acetylcholine was assayed using the radiochemical method of McCaman and Stetzler ${ }^{25}$ as modified by Marchi et al. ${ }^{26}$.

The results are summarized in Table I. These data demonstrate the presence of Met-enkephalin, dynorphin $\mathrm{B}$ and $\mathrm{ACh}$ in the rat cochlea. No significant changes in levels of these putative transmitter substances are seen at the different ages studied.

Enkephalin-like, dynorphin-like and choline acetyltransferase-like immunoreactivities have previously been reported to be co-localized in lateral olivocochlear cell bodies in the rat ${ }^{1}$. Although 3 classes of putative neurotransmitters are identified in the rat cochlea in this study, no change in their levels with age was seen. As auditory testing was not performed on these animals, it is possible that a deficit in auditory perception and cochlear transmitters may occur together at ages later than those studied. Hair cell losses have been reported to increase in the rat cochlea at even later ages ${ }^{22}$. However, aging changes in auditory perception have been reported in Fischer 344 rats with an average age of 25 months $^{29}$, which is the normal lifespan of these animals. Also, some pronounced differences in the aging of the rat and human cochleas have been noted, which may make the

1 Abou-Madi, L., Pontarotti, P., Tramu, G., Cupo, A. and Eybalin, M., Coexistence of putative neuroactive substances in lateral olivocochlear neurons in guinea pig and rat, Hearing Res., 30 (1987) 135-146.

2 Altschuler, R.A. and Fex, J., Efferent neurotransmitters. In R.A. Altschuler, D.W. Hoffman and R.P. Bobbin (Eds.), Neurobiology of Hearing, Raven, New York, 1986. pp. 383-396.

3 Altschuler, R.A., Fex, J., Parakkal, M.H. and Eckenstein, F., Co-localization of enkephalin-like and choline acetyl-

\section{TABLE I}

Levels of putative neurotransmitter substances at different ages in the rat cochlea

Values are mean \pm S.E.M., expressed in fmol/cochlea.

\begin{tabular}{llccc}
\hline & $n$ & 3 Months & 12 Months & 24 Months \\
\hline Enkephalin & 5 & $675 \pm 95$ & $733 \pm 129$ & $620 \pm 211$ \\
Dynorphin & 5 & $54 \pm 6$ & $63 \pm 4$ & $52 \pm 7$ \\
Acetylcholine & 5 & $1340 \pm 231$ & $1290 \pm 398$ & $1497 \pm 435$ \\
\hline
\end{tabular}

rat a less desirable model for studying neural mechanisms of auditory aging ${ }^{15}$.

The functions of these olivocochlear fiber systems are not clear at this time, in spite of much research, but are known to involve some inhibitory activity (see review by Wiederhold ${ }^{32}$ ). Nieder and $\mathrm{Nieder}^{27}$ reported that efferent stimulation increases the ability to detect sound stimuli in a noisy background, by increasing the signal:noise ratio. This discriminative ability rapidly declines with age, and is greatly impaired in neural presbycusis. It is well known that hair cells in many species decline in number or demonstrate damage with increasing age ${ }^{15.22}$. However, nothing is known to date about anatomical changes in the olivocochlear efferent neurons in aged animals of any species, although such information would be of great value in understanding the expression in the auditory system of the aging process.

This work has been supported by grants to D.W.H. from the National Institutes of Health (AG05499 and EY06180) and the National Science Foundation (BNS8646563). Cochleas were provided by Dr. Jeffrey Chesky of the Gerontology Program, Sangamon State University, with support from the National Institutes of Health to Dr. Chesky.

transferase-like immunoreactivities in olivocochlear neurons of the guinea pig, J. Histochem. Cytochem., 32 (1984) $839-843$

4 Altschuler, R.A., Hoffman, D.W., Reeks, K.A. and Fex. J., Immunocytochemical localization of dynorphin B-like and alpha-neoendorphin-like immunoreactivities in the guinea pig organ of Corti, Hearing Res., 17 (1985) 249-258.

5 Altschuler, R.A., Parakkal, M.H. and Fex, J., Localization of enkephalin-like immunoreactivity in acetylcholinester- 
ase-positive cells in the guinca pig lateral superior olivary complex that project to the cochlea. Neuroscience, 9 (1983) $621-6.30$.

6 Altschuler, R.A., Parakkal, M.H., Rubio, J.A., Hoffman. D.W. and Fex, J., Enkephalin-like immunoreactivity in the guinea pig organ of Corti: ultrastructural and lesion studies. Hearing Res., 16 (1985) 17-31

7 Altschuler, R.A., Reeks, K.A., Fex, J. and Hoffman. D.W., Lateral olivocochlear neurons contain both enkephalin and dynorphin immunoreactivities: immunocytochemical co-localization studies, J. Histochem. Cytochem., $36(1988) 797-802$.

8 Bobbin, R.P. and Konishi, T., Acetylcholine mimics crossed olivo-cochlear bundle stimulation, Nature (Lond.), 231 (1971) 222-223.

9 Eybalin, M., Cupo, A.A. and Pujol, R.. Met-enkephalin characterization in the cochlea: high performance liquid chromatography and immunoelectron microscopy, Brain Research. 305 (1984) 313-322.

10 Eybalin, M., Pujol, R. and Bockaert, J., Opioid receptors inhibit the adenylate cyclase in guinea pig cochleas, Brain Research, 421 (1987) 336-342.

11 Eybalin. M., Rebillard, G.. Jarry, T. and Cupo. A., Effect of noise level on the Met-enkephalin content of the guinea pig cochlea, Brain Research, 418 (1987) 189-192.

12 Fex. J, and Altschuler, R.A., Enkephalin-like immunoreactivity of olivocochlear nerve fibers in cochlea of guinea pig and cat. Proc. Natl. Acad. Sci. U.S.A., 78 (1981) $1255-1259$.

13 Godfrey, D.A., Krzanowski. J.J. and Matschinsky, F.M.. Activities of enzymes of the cholinergic system in the guinea pig cochlea, J. Histochem. Cytochem., 41 (1974) $270-274$.

14 Guinan, J.J.. Warr. W.B. and Norris. B.E.. Differential olivocochlear projections from lateral versus medial zones of the superior olivary complex, J. Comp. Neurol., 221 (1983) $358-370$.

15 Henry. K.R., Aging and audition. In J.F. Willot (Ed.), The Auditory Psychobiology of the Mouse. Thomas, Springfield, 1983, pp. 470-493.

16 Hoffman. D.W.. Altschuler. R.A. and Fex, J.. High performance liquid chromatographic identification of enkephalin-like peptides in the cochlea, Hearing Res., 9 (1983) $71-79$.

17 Hoffman. D.W., Altschuler. R.A. and Gutierrez. J.. Multiple molecular forms of enkephalin in the guinea pig hippocampus, J. Neurochem., 41 (1983) 1641-1647.

18 Hoffman, D.W.. Rubio. J.A. Altschuler, R.A. and Fex. J. Several distinct receptor binding enkephalins in olivocochlear fibers and terminals in the organ of Corti. Brain
Research, $322(1984) 59-65$.

19 Hoffman, D.W., Zamir, N., Rubio. J.A., Altschuler, R.A and Fex, J., Proenkephalin and prodynorphin derived peptides in olivocochlear fibers of the auditory system. Hearing Res., 17 (1985) 47-50)

20 Hoffman, D.W., Opioid mechanisms in the inner ear. In R.A. Altschuler, D.W. Hoffman and R.P. Bobbin (Eds,) Neurobiology of Hearing, Raven, New York, 1986, pp. $371-382$.

21 Jasser, A. and Guth, P.S., The synthesis of acetylcholine by the olivocochlear bundle. J. Neurochem., 20 (1973) 45-53.

22 Keithley, E.M. and Feldman, M.L., Hair cell counts in an age-graded series of rat cochleas, Hearing Res., 8 (1982) $249-262$.

23 Lehtosalo. J.I., Ylikoski. J., Eranko, L., Eranko, O. and Panula, P.. Immunohistochemical localization of unique enkephalin sequences contained in preproenkephalin $A$ in the guinea pig cochlea, Hearing Res., 16 (1984) 101-107

24 Lu. S.M., Schweitzer, L., Cant. N.B. and Dawbarn, D., Immunoreactivity to calcitonin gene-related peptide in the superior olivary complex and cochlea of cat and rat, Hear. ing Res., 31 (1987) 137-146.

25 McCaman, R.E. and Stetzler, J., Radiochemical assay for choline and acetylcholine: modifications for sub-picomole amounts, J. Neurochem., 28 (1977) 669-671.

26 Marchi, M., Hoffman, D.W., Giacobini, E. and Volle, R. Development and aging of cholinergic synapses VI. Mechanisms of acetylcholine biosynthesis in the chick iris, Dev. Neurosci., 4 (1981) 442-450.

27 Nieder, P. and Nieder, I., Stimulation of efferent olivocochlear bundle causes release from low level masking, $\mathrm{Na}$ lure (Lond.), 227 (1970) 184-185.

28 Norris, C.H. and Guth P.S., The release of acetylcholine (ACh) by the crossed olivo-cochlear bundle (COCB). Acta Otolaryngol, 77 (1974) 318-326.

29 Simpson. G.V., Knight, R.T., Brailowsky, S., ProsperoGarcia. O. and Scabini, D., Altered peripheral and brainstem auditory function in aged rats, Brain Research, 348 (1985) $28-35$.

30 Warr. W.B., Organization of the efferent fibers: the lateral and medial olivocochlear systems. In R.A. Altschuler, D.W. Hoffman and R.P. Bobbin (Eds.). Neurobiology of Hearing, Raven, New York. 1986, pp. 333-348.

31 Warr, W.B. and Guinan, J.J. Efferent innervation of the organ of Corti: two separate systems, Brain Research, 173 (1979) $152-155$

32 Wiederhold, M.L., Physiology of the olivocochlear system. In R.A. Altschuler, D.W. Hoffman and R.P. Bobbin (Eds.), Neurobiology of Hearing, Raven, New York. 1986. pp. $349-370$. 